\title{
DO DIREITO À EDUCAÇÃO E DA SUA CIRCUNSTÂNCIA: REFLEXÕES SOBRE EDUCAÇÃO EM DEMOCRACIA E SEUS OBSTÁCULOS
}

\author{
Paulo Ferreira da Cunha
}

\begin{abstract}
RESUMO
O direito à educação é um direito não apenas constitucionalmente consagrado e, como tal, um direito fundamental positivo, mas também um direito natural, decorrente da natureza das coisas e da necessidade vital de aperfeiçoamento da Pessoa. Ao contrário de alguns direitos que são concebidos como meras prerrogativas atribuíveis diretamente a beneficiários praticamente sem obstáculos ou refração, o direito à educação, pela sua natureza, também necessita para se efetivar de um ambiente propício e de mediadores: não apenas os veículos educativos, familiares, mediáticos e escolares, como ainda pessoas que desejem ser titulares ativos desse direito. No presente artigo são assinalados diversos aspetos da contextualização dessa "circunstância", como diria Ortega, deste direito singularíssimo, que tanto demanda a ação do Estado, como dos agentes educativos e culturais, como ainda e fundamentalmente dos cidadãos sujeitos e não objetos da educação. Pretende-se, assim, refletir de forma originária e sem complicadores ou preconceitos politica ou educacionalmente corretos sobre o Direito à Educação e os seus protagonistas, bem como sobre as suas dificuldades, que existem mesmo em contexto democrático.
\end{abstract}

\section{PALAVRAS-ChAVE}

Educação; direito à educação; democracia

\section{O PROFESSOR E O PODER}

Comparar ilumina. Quando contatamos o vasto e sábio mundo oriental percebemos claramente que o Ocidente está a fazer um hara-kiri educativo, por uma autoflagelação do seu património e uma subjugação dos seus professores, vítimas de todo o tipo de assédios morais, de muitas agressões até físicas e de uma desconsideração social suicida para a sociedade. Devemos pensar se muitos dos problemas políticos e sociais que temos não são devidos, em certos casos, a maus alunos terem conseguido pelo voto ou pela herança o que jamais conseguiriam pelo mérito. E esta situação de inversão de valores não é de modo nenhum benéfica para os discentes.

Numa utopia que imaginássemos, o "imperador" curvar-se-ia diante do Professor. Fá-lo-ia em representação da Sociedade, que tanto lhe deve. No Japão, estar-se-ia a meio caminho: O professor seria o único não obrigado a curvar-se diante do Imperador'. Pode ser mito, mas os mitos têm sentido e força.

\footnotetext{
' Retirado de http://www.cpp.org.br/siscon/print.php?2012/10/15/no-jap-o-o-nico-profissional-que-n-o-se-curva-diante-do-professor-o-professor.phtml.

Mas as opiniões dividem-se. Ver em http://ramanavimana.blogspot.pt/2012/o1/professores-japoneses-que-nao-se-curvam.html. Sobre a educação no Japão, ver o interessante livro de Nakagawa (2008).
} 
Só pela educação é possível a Liberdade. Liberdade que nos distancia da natureza e nos faz diferentes dos animais, puramente instintivos. Só pela Educação adquiriremos instrumentos de superação da "necessidade", da nossa "circunstância". Mas o que seja educação está em grave crise. Há quem se julgue dela dono e senhor, e contudo, se revele incapaz de educar, e mesmo até um entrave a que alguém eduque e se eduque.

Educar é tarefa comum, social, de todos e cada um. Não deve assim renunciar cada cidadão (por frágil que seja) ao seu poder-dever de educar. Cada um de nós tem uma centelha que deve comunicar. Grande parte dos problemas civilizacionais que temos decorre da demissão de pais, parentes, vizinhos, circunstantes, na correção pronta de pequenos prevaricadores anti-sociais. Além do défice na formação em casa.

A escola sozinha pode pouco. Encontra-se cada vez mais condicionada por normas e dirigentes que insistem na exclusividade da instrução, sem formação. Ressentindo-se do facto de haver pais de alunos que desautorizam, quando não agridem impunemente, professores mais interventivos, menos laxistas.

Os média são, no essencial, mais anti-formadores que formadores. Pagos pelos anunciantes, cultivam o fácil e o "popular", desde logo, nas mais elementares pulsões: violência, sangue, sexo, escândalo, jogo, sonhos impossíveis, mexericos, e afins, além das notícias deprimentes do que de mal corre no mundo e se abate sobre as nossas cabeças.

Serviço público mediático, com claro compromisso formativo, infelizmente não se vê muito: uma ou outra flor na botoeira, sempre ameaçada de extinção. Aliás, as falências de pequenos produtores e distribuidores nos domínios da arte, da comunicação, das ideias, tem vindo a exponenciar-se. Porque educação e cultura não propiciam anúncios, ou se pensa assim. Mesmo quando programas culturais têm público, decreta-se dogmaticamente que são elitistas. Melhor se faria se se atentasse nos números reais da economia cultural, surpreendentemente altos, pelo menos em situações de normalidade. Mas parece tratar-se de um negócio em que quem investe não será normalmente quem virá a lucrar. A educação e áreas afins, como a cultura florestal, é um empreendimento intergeracional: exige políticas a médio e a longo prazo. É preciso deixar o tempo fazer crescer.

Há portanto preconceito ideológico anticultural, e não só mero economicismo, essa tendência tão contemporânea para valorizar "o preço de tudo e o valor de nada", como observou Oscar Wilde. E há, todavia, vistas curtas.

O poder que teme o Povo, não o quer ensinar. O que ama o Povo precisa absolutamente que ele seja esclarecido e que o reconheça. Há poder que só se mantém pela ignorância, e poder que só chega a sê-lo pela inteligência popular, pela informação, pela cidadania.

Espanta que alguns tipos de poder que se diria só poderem manter-se pelo esclarecimento popular frequentemente tenham comportamentos muito displicentes quanto à educação. Será a lei de bronze da falta de recursos apenas, ou a distração e otimismo de quem pensa que será necessariamente reeleito, com ou sem esclarecimento? Será que esse esquecimento do que mais importa decorrerá do facto de, nas democracias, as decisões políticas serem pautadas pela agenda eleitoral de curto prazo? Mas, mesmo assim, educar não dará mesmo votos? Ou haverá outras razões? 


\section{SOCIEDADE E ESCOLA PLURAIS E PLURALISTAS}

Nunca pensámos que, sem censura, as opiniões pudessem ser tão diferentes, tão diversificadas, tão imaginativas. Contávamos com pluralidade, mas não com um colorido tão grande. E uma das razões por que críamos o leque mais curto não é revelador de algo muito positivo: acreditávamos que as pessoas, em geral, teriam mais bom senso, mais bom gosto, mais educação e mais instrução. O que recoloca o problema básico da educação multidimensional como prioritária em qualquer democracia.

Juntem-se indignação, frustração, falta de dinheiro e uns lugares comuns mal digeridos e, só por isso, já teremos argumentos? Não se nos afigura ser esse um caminho proveitoso. Seria preciso, mesmo nas crises, procurar ultrapassar a circunstância e pensar com dados e razão.

Há um excesso de subjetivismo e de emotividade no barril de pólvora do crescente desemprego num contexto de desmantelamento do Estado social e, para além de todos os factos, numa situação de indignação face à corrução, às mordomias, à duplicidade de muitos políticos. Sem esperança, eleva-se o discurso radicalizadíssimo da demolição, que nada distingue.

De novo sempre assoma a questão epistemológica de mãos dadas com a deontológica.

Não é hoje muito comum universitários europeus assumirem posições científicas que podem, de uma forma ou de outra, ser consideradas políticas. Há um nem-nem-ismo e uma pretensa "linha branca" no mainstream académico que olha de soslaio para os que afirmem o que quer que seja. Evidentemente que um Barthes (1970) e um Fiske (1999) desconstruiriam esta tendência para pretensamente ninguém se comprometer com coisa alguma, na verdade pactuando com tudo...

É de saudar que em algumas universidades (vimos isso, pelo menos, em anglófonos e brasileiros) cada um se possa assumir como é - sem proselitismo e muito menos favoritismo por alunos feitos adeptos, e colegas correlegionários - com a liberdade de dizer o que pensa, mesmo em matéria tão sensível como uma ideologia de sistemas económicos e uma ética. Contudo, já algures algum deputado propôs a proibição de que um professor fale de política nas escolas. Vai proibir os cursos de ciência, sociologia, filosofia política? E a meio (ou mais) os cursos de Direito, Filosofia, Sociologia e afins?

Ora uma Universidade em que se pode ser o que se é, é uma verdadeira Uni-diversidade, que é o que a Universidade tem de ser, por natureza: um local de debate plural e livre de ideias, antes de mais. E trata-se assim não apenas de contribuir para que se supere a proverbial trahison des clercs, de que falava Julien Benda, significativamente já em $1927^{2}$.

Há intelectuais que não traem, nem se traem. Estão engajados, e é esse engajamento um enriquecimento, ao contrário do que possa pensar-se. Obviamente não se fazem (não se devem fazer) comícios em aulas, mas o professor não é um eunuco ideológico. Não ensina a pensar se não puder ensinar o que pensa, abrindo-se ao confronto,

\footnotetext{
${ }^{2}$ Sobre os intelectuais hoje são interessantes as abordagens Fiske (1999) e Bauman (2010).
} 
à dialética, segundo as regras depuradas da academia. Nocivos são os "professores" que, sob a capa de pretensa assepcia, debitam, inoculam, ideologia a rodos e por todos os póros a exalam...

$\mathrm{Na}$ verdade, muita dessa pseudo-neutralidade faz passar os estudantes por débeis mentais ou débeis políticos, vítimas indefesas da lavagem ao cérebro dos docentes. Uma das formas de reconhecimento da maioridade e autonomia dos estudantes - e essas são as grandes conquistas das Luzes, tais como as viu Kant (1988) - é dar-lhes a liberdade de escolha sem pear os docentes em vulgaridades (e quanto haveria que dizer sobre o confiscar-lhes o tempo de pesquisa com burocracias nocivas mais que improdutivas), impedindo-os de dizer o que pensam. Se cada um disser o que pensa, e se as escolas recrutarem pluralmente, não há perigo de intoxicação mental. Pelo contrário, há abertura de amplas janelas do espírito.

Mas aí está outro problema: é preciso garantir o pluralismo no recrutamento. Ora até que ponto a autonomia levada ao extremo não propicia a reprodução das mesmas ideias e das mesmas ideologias? Ou, por outro lado, a não autonomia...

A solução fácil seria a das quotas... Mas uma Universidade, uma escola, não é um parlamento. A tentação seria logo que houvesse recrutamentos ideológicos, no limite partidários, e refletindo os resultados eleitorais, ou a procura do "mercado". Não é nada simples... E muitos especulam sem limites. Se tiverem poder para aplicar pesadelos, pior.

Contudo, o problema do pluralismo na Universidade é deveras um problema. Não se trata de propugnar um pluralismo aritmético, mas são necessários freios e contrapesos, que permitam que uma aula ou uma palestra não sejam uma conversa de café entre amigos, e, pior ainda, entre correlegionários, de partido, de classe, de clube, de ideologia, de religião ou de orientação filosófica...

\section{DA VELHA E DA NOVA ESCOLA E DA NOVÍSSIMA}

Há que trabalhar na Educação das Pessoas articuladamente: na geral e na cívica, e na jurídica, claro... Mesmo que não houvesse resistências e escolhos mil (e cada vez parece surgirem mais), ainda haveria tanto que fazer.... E os principais obstáculos a uma vida coletiva medianamente sã (não se pede sequer a utopia) são a cobiça, a inveja (Gillman, 1996) e a vaidade - que levam a que a razão se tolde, com todos os monstros que assim se engendram. É verdade que a Política deve estar primeiro: Politique d'abord! Mas a prepará-la tem de estar uma sólida, esclarecida e livre Educação. Naturalmente a Educação precede o Direito - Paideia telion ton nomon.

"Antigamente a escola era risonha e franca..." - dizia um proverbial poema, que as pessoas sabiam de cor, mesmo muitos anos depois de saírem da escola (Antunes, 2015; Cunha, 2011). Era, assim, parte integrante da cultura geral, isso "que permanece, depois que esquecemos o demais"...

As coisas mudaram muito... A educação de antigamente (do antigamente mais próximo, claro) era uma prisão, em muitos sentidos: uma esclerose ideológica, um mundo a preto-e-branco, um autoritarismo profundo, só moderado pelo facto de muitos 
professores se lhe furtarem, porque eram (dir-se-ia "por natureza") democratas e não se identificavam com o sistema. Eram heróis.

Essa educação, com todos os seus defeitos, preenchia, apesar de tudo, (embora cheia de antolhos e para um círculo restrito, é certo) algumas funções que a atual não consegue suprir: autoritária, tinha um fumus de autoridade - e sem autoridade, e sem docilitas do estudante, não há ensino; memorizadora, dava algumas bases concretas e factuais ao estudo, sem as quais a inteligência flutua sem objeto; aparelho ideológico do Estado, mantinha por isso, apesar do pauperismo em que (como hoje) conservava os docentes, a aura de prestígio para quem ensina, que as Repúblicas tinham glorificado. Com a democracia, o laxismo invadiu as escolas, que não entenderam ser esse um calcanhar de Aquiles que lhes pode custar a vida. A escola ainda não lida bem com a multiculturalidade (não sabendo por isso assumir um equilibrado multiculturalismo) nem sequer interiorizou completamente as necessidades de adaptação requeridas pela mera escolaridade obrigatória: ignora, aliás (dizendo que convive com, ou que tolera) o que não conseguiu ainda pensar, absorver, ou expulsar.

E, evidentemente, a partir do momento que a primeira fornada de maus professores saíu diplomada e a fazer os seus estragos, a reprodução passou a dar-se em cadeia (Cunha, 2005a). Contudo, do mesmo modo que há alunos bons que se salvam apesar de mau ensino, também há professores de geração espontânea, que conseguem sê-lo apesar de terem tido maus mestres... Felizmente, basta um único bom professor para salvar um aluno.

A novíssima escola que é preciso construir terá que revalorizar os docentes ${ }^{3}$. Redemocratizar-se, ao nível institucional, mas recuperar, em clave democrática, a autoridade, o culto pelo saber, pelo debate elevado e sério, o esforço (Calafate, 1999) que conduz ao prémio, e o prémio que conduz ao esforço. Toda a arte, toda a ciência deve ensinar-nos que a disciplina não é incompatível com a liberdade: andam a par, como a tensão física de uma corda que se afine.

Se não for para atingir os objetivos de que falámos (que são objetivos em progresso, em contínuo constitutir-se), a escola servirá apenas de depósito de crianças e jovens. Como na saborosa expressão castelhana para "jardim de infância" ou cheche: "guardería". E mesmo assim nem sempre conseguindo guardar de vários perigos e males.

O movimento da Filosofia Portuguesa (Calafate, 1999), pelo menos em alguns dos seus cultores, tinha no seu cerne a luta contra a pena de morte, contra a pena de prisão e contra os exames académicos. Afigura-se-nos cada vez mais atual essa trilogia. Obviamente cum grano salis, e até na sua radical provocação.

Muitos não se apercebem quão longe cada uma das reivindicações nos levaria. Porque continua a haver pena de morte, pena de prisão, e exames académicos. E de que maneira. Porque é um problema que radica mais profundamente no desamor coletivo (Botelho, 1996).

Assim, mesmo que a primeira das referidas penas (ou "penares") seja inconstitucional, há, por exemplo, pena de morte na condenação de pessoas a cadeias onde serão

\footnotetext{
${ }^{3}$ Entre vários ver Cunha (2011).
} 
inevitavelmente contagiadas com doenças mortais, ou pena de morte na demissão estadual da prestação de cuidados médicos sem os quais a morte necessariamente ocorrerá.

Há decerto alguma ambiguidade em penas de prisão não apenas ineficazes quanto aos fins que normalmente devem perseguir, limitando-se, em muitos casos, na dupla função de armazém inóspito e insalubre de pessoas a quem se retira a mobilidade e o convívio social normais (ex-comunhão, ex-comunicação) e a quem se pode dar, em contrapartida, uma vida infernal ou um ingresso na escola avançada do crime ${ }^{4}$.

Finalmente, os exames académicos de novo denotam grande ambiguidade. Muitas vezes não servem internamente à escola: não desempenhando a função de boa seleção dos melhores, por exemplo pelo privilegiar da erudição ou do tecnicismo; ou, pelo contrário, em situações de laxismo dececionam quem estudou realmente e quem tem qualidades pela sua parificação demagógica com todos os demais. E externamente de pouco servem, em muitos casos, a titulação académica e a mais classificada graduação, porquanto a sociedade, vivendo em grande medida de empenhos, não presta a devida atenção aos que penaram para obter os seus títulos, e até com as maiores honras. Por outro lado, que diferença tem relativamente ao exame uma avaliação dita contínua ou progressiva em que apenas se martirizam os estudantes com mais exames ao longo dos anos ou semestres? Muitas vezes essa permanente avaliação é ainda mais confiscatória da liberdade de aprender que o exame final, massacre ao menos localizado.

De que servirá, pois, um sistema em que a morte vem travestida de prisão e a prisão é sempre morte social, enquanto a escola é antecâmera enclausurante para novas prisões, nomeadamente laborais, se não mesmo penais? São tudo mortes e prisões, de mais fundo significado antropológico e até metafísico.

Cada vez mais atual a trilogia.

E não se pense que os exames são irrevogavelmente necessários. Nem sequer úteis. Mas, para os abolir, seria preciso que as cabeças e os corações mudassem muito. Infelizmente, proliferam os plágios por todo o mundo, e outros expedientes para contornar a avaliação.

Certo é também que a avaliação extrauniversitária, a dita avaliação "pela sociedade", tão elevada aos píncaros pelos neoliberais, não é avaliação: demasias vezes, ou é sorte, ou é "cunha" ("empenho") de quem tem e pode. Não é, pois, a sociedade que avalia quem vai à luta, quem se faz vida. A sociedade já tem o seu entendimento distorcido pelo tipo de universidade que se cursou, pelo nome do indivíduo (e seus pais), pela sua condição social, etc. E por quem o apadrinha. Enfim, a mão invisível é tudo menos invisível e tudo menos justa.

Nesse sentido, uma escola pública ${ }^{5}$ que avalie seriamente (relegando a abolição dos exames para sociedade mais perfeita) e cuja avaliação tivesse que ser tida em conta pela sociedade, seria um elemento de positiva procura da Igualdade. Desde logo, igualdade de oportunidades. Nem seria necessário ir mais longe.

${ }_{4}^{4} \mathrm{O}$ caráter criminógeno das instituições prisionais é conhecido. Numa perspetiva mais abrangente, por todos, ver Chiossone (1987). O que não quer dizer, obviamente, que estejamos em condições reais de soltar criminosos perigosos.

${ }_{5}$ Obviamente sem prejuízo do direito de criar e manter instituições educativas privadas, sob o controlo de qualidade dos governos e de acordo com critérios objetivos e sindicáveis. 


\section{EDUCAÇÃO, COMUNICAÇÃO, LIBERDADE E SERVIDÕES}

Em certo sentido, e até certo ponto, como dizia Rousseau (2010, pp. 6-7), é preciso obrigar as pessoas a terem instrumentos de liberdade. Como as crianças que vão obrigadas à escola.

Em geral, aprende-se a gostar. Voltando a Rousseau, é sempre triste ver como os "escravos mais vis" se riem, fazendo chacota, da palavra Liberdade (Rousseau , 2010, p. 12) ${ }^{6}$.

Uma das primeiras manifestações desse "obrigar à Liberdade" é pois, necessariamente, a educação para os direitos humanos, para a cidadania e a própria educação constitucional, que não pode limitar-se a juristas, mas estar à disposição de cada cidadão, na sua versão básica, no ensino secundário ao menos, quando não inculcados desde a escola elementar, e antes disso nos lares, primeiras escolas de todos. No Brasil foi apresentado um projeto de lei para o estudo generalizado da Constituição nas escolas, mesmo elementares?.

Não se entende sequer que a Constituição, lei das leis, não seja sistemática e profundamente ensinada em democracia nas escolas secundárias ao menos, quando, em ditadura, a ordem constitucional (pseudo-constitucional) de então tinha direito, por exemplo em Portugal, a uma disciplina autónoma ("Organização Política e Administrativa da Nação"). Seria por mero intuito legitimador por parte do Estado Novo? Ou um resíduo de cidadania, devida à formação inevitavelmente republicana que tiveram os seus dirigentes, apesar da sua inclinação autoritária? Para muitos assim funcionou: ensinava-Ihes uma linguagem em que podiam doravante até discutir o que parecia indiscutível. Parece também que disciplinas de "marxismo", nos países do Leste europeu antes das "quedas dos muros", e até o direito corporativo em Portugal eram pretexto para, desde que em sábias mãos, alargar os horizontes muito para além do pretendido com a sua instituição.

Seria entretanto interessante fazer-se um estudo comparatístico sobre o estado deste tipo de estudos, em diversos países. Cremos que idêntico descaso se encontraria em várias democracias.

Falava Rousseau sobre escravos... A escravatura sempre andou mais ou menos envolvida em mistério e em mistificação ${ }^{8}$. Até porque é difícil afirmar com segurança onde começa e onde acaba. Aristóteles teria razão: há escravos por natureza? (Aristóteles, 1987). Tal tese, além de matizada, tem que ser vista em várias vertentes. Há os que têm a compulsão, pelo dever e até pela necessidade anímica, de trabalhar, mas não de servir, e os que vivem para trabalhar e para servir ${ }^{9}$. Ou mesmo para servir não trabalhando... Depois, há mil e um outro tipo de preguiçosos, fúteis, etc. O problema dos que trabalham compulsivamente servindo é que não são solidários com os poucos que o fazem, mas não aceitam tudo o que lhes exijam.

\footnotetext{
${ }^{6}$ No original: “ (...) de vils esclaves sourient d'un air moqueur à ce mot de liberté”.

7 Projeto de Lei $n^{\circ} 6954$, de 2013.

${ }^{8}$ Cf. Cunha $(2011,2012)$

9 Coisa diversa é a "servidão voluntária" de que fala La Boétie (1997).
} 
E temos ainda o testemunho de Pitágoras:

A maior parte dos homens são escravos: uns da glória, outros da fortuna. Há, todavia, um pequeno número que, desprezando tudo o mais, têm por ocupação apenas o estudo da natureza; são esses os que se designam a si próprios por amigos do saber (...) ou seja, filósofos. (Pitágoras citado em Vilhena, 1942, s/p)

Complicado... Não será possível fugir da escravatura, mesmo não sendo filósofo? Isso poderia ser um ideal normal de vida. E de cidadania. Meta: fugir da escravatura, de todas as escravaturas. Caminho que, num limite, é solitário. No outro, solidário.

Não há verdadeira liberdade quando importantes grupos de opinião (e mesmo pessoas) não encontram eco nem "tempo de antena" na comunicação social dominante. Quem não está na televisão não existe, numa sociedade de espetáculo como a nossa. E só existe politicamente e culturalmente quem vai à televisão. Não tenhamos ilusões. Ou devemos tê-las, diversificando os nossos meios de comunicação, embora a questão seja mais lata, e vá desembocar à propriedade e manipulação dos grandes órgãos.

Entretanto, as redes sociais e a Internet em geral fazem o seu caminho de projeção, mas cremos que, se conseguem já convocar manifestações políticas de relevo, e formar alguma opinião, ainda não conquistaram a audiência passiva das massas. Pela sua natureza de interatividade, não têm esse tipo de audiência. Ora o domínio televisivo impera em grande medida pelo seu efeito narcotizante.

Combinemos as opiniões de Sartori (1994) e de Lembo (2006), em conjunto com as já evocadas por Caggiano:

Sartori convoca o homo videns para caracterizar o cidadão que habita o cenário atual:oserpostadodiantedoaparelhodetelevisão, ausente, absorvendosomente imagens, asimagensqueamídia entendeoportunolheoferecerparaalimentá-lo. Enfim, cada época traz os seus 'néscios', como registra Lembo ao lembrar a eterna presença na comunidade social de personagens que, despidos de quaisquer sentimentos ou de respeito pelos demais habitantes do planeta terra, fazem irradiar os efeitos nocivos de suas ações ignorando por completo tudo que os cerca. Cada um deveria procurar o seu néscio, adverte Lembo. (Caggiano, 2011, p.6)

Não são boas notícias, mas há que encará-las com objetividade.

Voltemos um pouco atrás. Antigamente, quem queria falar e era heterodoxo, criava os seus próprios jornais. Precisava, para isso, de meios. Contudo, riqueza individual ou solidariedade (Black, n.d.) coletiva ainda conseguiam, em muitos casos, alcançá-las (Blais, 2007). Os desaires eram frequentes, mas a falência de uma voz era substituída por vários novos projetos mais ou menos confluentes.

Hoje há outro problema: quem lê os jornais? Escassas pessoas. Tudo parece estar hipnotizado perante a televisão, a que já se chamou "one-eyed monster". Talvez o caminho passe pela informatização massiva, afinal arma de dois gumes, sempre. Se ela obriga 
a uma disponibilidade permanente do trabalhador escravizado de hoje, um mundo online não precisa de notícias cozinhadas por redações televisivas e mesmo jornalísticas ou radiofónicas. Donde haja correntes na comunicação social que consideram ser futuro desses media especialmente a "coluna de opinião" e não o debitar de conteúdos informativos a partir dos seus repórteres e correspondentes e de mais globais agências noticiosas.

Não vale de nada o lamento sobre o não se conseguir entrar na presente comunicação social: é reduto fechado. Um político caído em desgraça confessou uma vez que teria que passar a dizer (quiçá a fazer) coisas chocantes para ter tempo de antena.

Como se pode pensar que os media darão voz a quem não esteja em sintonia? Por vezes ainda acontecia noutros tempos, graças ao espírito aberto de um ou outro: mas parece ser cada vez mais raro. Hoje criam-se blogues e afins na Internet, como Ersatz... e chegam a convocar-se manifestações por telefone portátil, e não por motivos fúteis. Para a cidadania, porém, não ter acesso à televisão é como, para a vida, não ter acesso à água potável. Por ter tido já uma intuição dessa importância é que a Constituição Portuguesa de 1976 constitucionalizou formalmente o "direito de antena" (art. ${ }^{\circ} 40$ ). Contudo, em termos muito tímidos - como certamente não poderia deixar de ser, dada a sede em causa. Porém, não poderia a lei ordinária ser mais generosa e ir mais além no abrir a janela da cidadania (ou não) a mais rostos e a mais vozes, e por mais tempo? Pior ainda que os programas culturais, dirão certamente os peritos em audiências dos programas políticos. Mas não são só estes. É a voz da criação autónoma e da cidadania. Outra questão a amadurecer, sem precipitações, mas com a sensação clara de que as nossas democracias falham pela incapacidade de dar voz as produtores independentes de sentidos.

Por outro lado, poderá vir o tempo em que a antena de que se precisa não seja só a televisiva ou radiofónica. Espera-se que, entretanto, não seja necessário introduzi-la, porém, no cyberespaço, já que se deseja que continue, como em geral é, bastante livre e não controlado.

Falemos um pouco de educação jurídica (Cunha, 2016, pp. 125-146). É gritante, muito para além do imaginável por um mediano jurista, a incultura jurídica e política de muitos dos nossos concidadãos. Julgamentos populares, revisões constitucionais por abaixo assinado na Internet, ostracismo declarado contra políticos pela mesma forma, incitamento a tiro nos deputados quando vierem de novo pedir votos, mil e uma ideias obtusas, que de uma penada violariam não só dúzias de leis, como a Constituição e os grandes princípios até supraconstitucionais ou transcontitucionais ou constitucionais globais (esses que todas as Constituições, no nosso nível de civilização terão de respeitar).

Mesmo pessoas cultas acham a linguagem jurídica hermética e aborrecidíssima, além de perda de tempo, ecrã de fumo, etc. Compreende-se que, para quem não é jurista, os textos jurídicos façam adormecer, como para quem não é filósofo alguns filósofos façam cochilar, como para quem não é médico os termos médicos sejam incompreensíveis, e não sendo nós mecânicos de automóveis achemos sempre que aquilo que nos dizem em garagens é puro esoterismo. E alguns, com ressalva da honra e consideração profissionais dos mecânicos, colocam dúvidas se tanta complicação não esconderá charlatanismo (Black, n.d.; Quintino, 2007). 
Esta incultura jurídico-política é muito grave, sobretudo em tempos de crise, em que não se sabe quem poderá vir a decidir do justo e do injusto, do legal e do ilegal. Seria preciso lançar pontes para a inteligibilidade. Sem o que o jurídico perde legitimação pelo discurso, que hoje em dia não se pode desperdiçar. Porque falta educação jurídica e os Direitos para todos (como deveria ocorrer, em defesa até da própria democracia), ainda muitos não viram que a Constituição é a pedra de toque e a grande linha divisória: entre democracia e ditadura, entre pobreza e vida digna, entre legalidade e arbítrio.

Para a educação começa a haver alternativas curiosas. A maioria dos slogans de autoajuda e motivação na comunicação social, desde anúncios a redes sociais, são a favor do egoísmo, ainda que embrulhado em auto-estima e competitividade, até porque há um crescente público consumidor e dependente dessa "literatura". Não é socialmente corrreto dizê-lo, mas trata-se de um fenómeno que deveria ser motivo de estudo, porque tem necessariamente consequências, evidentemente políticas. A cidadania, aliás, não parece muito nas preocupações da maioria dos conselhos. É antes o cuide de si mesmo, "vá à luta", e afins. Para as solidões não se receitam solidariedades - é curioso.

Um olhar desconstrutor verá neste movimento social (que o é) a insinuação da ideologia do "salve-se quem puder", a promoção do individualismo. Em geral, a ideia é as pessoas passarem a ser espertas, não repetindo a sua bondade (confundida facilmente com ingenuidade e até estupidez) para com os outros. Ora não nos deveríamos arrepender de ter feito coisas pelos outros, antes de não termos feito as suficientes.

Esta subtil forma de educação não é, como poderia parecer, para a liberdade, mas para a dependência do ópio da auto (eventualmente hetero-) ajuda, e inculca nas pessoas o vírus do individualismo feroz, e os complexos do perdedor (loser). Insiste-se que só não triunfa na vida quem intrinsecamente não vale ou não trabalha (Aristóteles, 1987; Quintino, 2007). Ora, pelo contrário, escassíssimos (e normalmente com as cartas marcadas) podem triunfar no mundo de roleta e loucura... que seria apenas um pano de fundo normal, natural e plácido, tudo dependendo da mentalização, da visualização, do autoconvencimento do samurai do triunfo, empresário de sucesso, e outros estereótipos com que se pretende iludir e fazer trabalhar os iludidos até uma morte precoce e por exaurimento.

\section{DiÁlogos}

Há princípios que nos devem aderir à alma, ou quiçá dela fazerem já parte: como o de sempre termos obrigação de dialogar; e o diálogo, muitas vezes parecendo de surdos, traz quase sempre novos ângulos para os nossos pontos. Não é pois totalmente desperdiçada a polémica, mesmo com quem seria preciso tentar colmatar muitas lacunas, de dados e de interpretações. Não tanto pelo efeito que a nossa palavra possa fazer no interlocutor, mas pela variedade de surpresa de argumentos, quantos deles sem pertinência, mas que alargam os horizontes, e, no limite, fazem entender a Humanidade. Ou para tanto vão dando achegas.

Aristóteles, nos Tópicos do seu fundante Organum, postula, e bem, que não pode haver discussão sem que se parta de alguma base consensual. E diz que há coisas que 
se não admitem à partida num discurso, como o questionar o respeito pelos deuses e os pais e negar que a neve seja branca:

Quem proponha a questão de saber, por exemplo, se é preciso ou não louvar os deuses e amar os pais, não pede mais que uma boa correcção, e quem pergunta se a neve é branca ou não, só tem que abrir os olhos. A controvérsia nunca se deve criar nem acerca de assuntos cuja demonstração é próxima, nem acerca de assuntos cuja demonstração é longínqua. No primeiro caso, não há qualquer dificuldade e, no segundo, as aporias são muito grandes para um simples exercício disputativo. (Aristóteles, 1987, p. 30)

Cremos que são dois exemplos paradigmáticos, remetendo um para os dados "evidentes" dos sentidos individuais e outro para os valores morais vigentes numa sociedade, sem os quais ela certamente implodiria, evidentes por isso também do ponto de vista social.

Mas há mais: é preciso acordo sobre factos, sobre procedimentos, etc. Caso contrário, todo o diálogo é de surdos. Às vezes (para mais em sociedades multiculturais, em que os cânones de vária ordem só muito residualmente assim permanecem, e as coisas mais básicas fazem falta elementar), responder a alguém implicaria ter de lhe facultar, concomitantemente, um imprevisível conjunto de informações sobre história, direito, política, quando não mesmo de regras de bom convívio básico, que podem ir da lógica aos rituais de boas maneiras. Portanto, não se pode realmente pensar que se está cabalmente a falar, ou a escrever: qualquer coisa que se diga certamente não irá atingir o efeito desejado. Mesmo um esforço para nos traduzirmos pode ter consequências imprevisíveis. E mesmo assim há que não ficar calado, e tentar ser entendido.

Pior porém é não querer entender. Há também os que, falando e polemizando, não querem ouvir nada dos outros. Todos os pretextos são bons para descarregar a sua teoriazinha, a sua vaidade, o seu sectarismo, a mesmo sua raiva, mais ou menos envernizada de civilidade e boas maneiras. O que ocorre, porém, é que discurso inflamado da paixão sectária não aproxima ninguém da verdade, e só afasta quem o faz dos interlocutores que não partilhem, desde logo, das suas experiências, e depois dos seus juízos.

E no meio da geral vozearia (a comunicação pelo simples comunicar - fática - aumenta exponencialmente) e da profunda incompreensão, ilegibilidade, e falta de sintonia, mal-entendidos potenciadores de desavenças, o Direito não pode. E a todos tem de aplicar-se, quer o entendam, quer não. Nisso, os juristas têm - na legitimação pelo discurso - de ter um papel de tradutores universais. Ingrato papel, para que as Faculdades de Direito normalmente só muito remota e lateralmente preparam. Mas ainda assim podem preparar e até ter preparado. Porque nem só o que explicitamente se aprende é realmente aprendido.

Quantas matérias importantíssimas se colhem da anedota, do àparte, da breve reflexão à margem desses mestres que o foram e são verdadeiramente. Quanto se aprende dos labores árduos e aparentemente não de imediato aplicáveis. Quanto se aprende do dito e do não-dito. 
Mas o esforço pela clareza possível, pelo diálogo possível, pela compreensão possível em sociedade é de todos os dias, e um labor de Sísifo a que não pode o jurista renunciar.

Algumas grandes e sangrentas polémicas e guerras decorrem apenas de que uns conhecem certos dados, e outros os ignoram, de que uns têm certos instrumentos e treino hermenêutico, e outros não. E quanto mais se ignora o vasto mundo, mais se cuida estar à vontade num mundo que, embora realmente fechadíssimo, se tem por conhecido.

Um dos grandes problemas do diálogo democrático é, além de se estar ou não de boa fé, este outro: o entender-se ou não se entender o que o nosso interlocutor diz. Mas é tido por snob que alguém tente explicar, ainda que com todos os cuidados, que não foi entendido, por deficiência de compreensão, falta de cultura, etc. É que é raro que o ignorante - que normalmente não tem nenhuma culpa em sê-lo - levar a bem que se suspeite sequer que o seja. Mas será democratica e civicamente lícito deixar alguém na sua nesciência? Não é obra de misericórdia espiritual ensinar os que erram, de várias maneiras e por diversos motivos? Errar é, aliás, a terceira obra de misericórdia depois de dar bons conselhos e de ensinar os ignorantes (Debord, 1992; Debret, 1993; Portal Ecclesia, 2012). Mas não é dever cívico corrigi-los?

Não se encontram as respostas afirmativas a esta questão no rol das soluções consideradas hoje politicamente $\operatorname{corretas}^{10}$. Mas ou a democracia as enfrenta com lucidez e prudência, enquanto tal, ou outro regime não terá pejo em impor pela força as suas convicções, mesmo o mais dogmáticas e absurdas que que possam ser.

Já houve poderes que se incomodaram com o clamor das gentes... Hoje são as gentes que se incomodam com o clamor dos poderes.

Vivemos numa sociedade de espetáculo, onde o Estado deseja seduzir os cidadãos (Debord, 1992) - quando se não queixe deles e da sua imperfeição"'. Os poderes não moderam a sua presença na vida das pessoas (quando se não desejam ornar de prestígio por uma certa discreção - o que vai sendo raro dada a tentação mediática a que normalmente o poder não consegue furtar-se), e bombardeiam de "factos" (e sabemos como os factos políticos são em grande medida criados, ou inventados) os cidadãos espectadores. Perante a encenação e o assédio, é grande a tentação de apagar essa realidade intrometida (e em excesso portadora e criadora de más notícias), fechando a "antena": a rádio, o computador, a televisão'2. Para muitos é um "clic" de higiene cultural e paz de espírito. Pois se as notícias a que nos julgam com direito (ou será com dever?), por toda a parte, são formas de "choque", por que estarmos à mercê delas quotidianamente? Há mesmo algum sentido e direção nos poderes que determinam a sorte das pessoas

\footnotetext{
${ }^{10}$ Boa parte das ideias que repetimos em matéria política é moldada pela chamada "correção política". Ela é normalmente uma outra versão, educada e soft, do pensamento dominante, com todas as suas contradições. Cf. (Beard \& Cerf, 1994; Guitar Escudero, 2005).

" “(...) O povo perdeu a confiança do governo / E só à custa de esforços redobrados / Poderá recuperá-la. Mas não seria/ Mais simples para o governo / Dissolver o povo / E eleger outro?" (Brecht, 1976, p. 82)

${ }_{12}$ Derrida (1991), lembra a solução de pura e simplesmente apagar a televisão que teria sido proposta pelo Papa João Paulo II.
} 
concretas? Ou todos são vítimas da estrutura, do sistema, como parece pensar o antigo ministro Luc Férry ${ }^{13}$ ?

Não sendo possível a construção de uma global Arcade Noé (e recordemos quão plutocrática era a seleção para a do filme 2012 (Emmerich, 2009), a atitude é frequentemente negativa: negar essa realidade incómoda que entra pela televisão. Ou então - mais frequentemente ainda - passiva: deixar-se adormecer no sofá, embalado pela ama-seca teledifusora.

E no entanto há certas pessoas que é bom escutar, quando falam, e melhor ainda quando resolvem não falar. Há uma retórica da palavra e uma retórica do silêncio (Fumaroli, 1994; Hall, 1959; Ryner, 1996).

Só quem aprendeu a calar e a ruminar (não como submissão, mas como aprendizagem superior) merece o dom de ter a palavra. Normalmente quem fala sem pensar não acerta. É preciso pensar-se tudo o que se diz, mas não dizer-se, nem de perto nem de longe, tudo o que ocorre ao pensamento.

Falar na esfera pública deveria implicar um domínio do decorum, da oportunidade, até de alguma raison d'Etat. Infelizmente, a nossa democracia é antes, em grande medida, uma logocracia demagógica. Não se trata, como é óbvio, de censura. Mas de auto-contenção. Não pelas conveniências, mas pela conveniência comum, ou bem comum. Mais um problema da mais alta e mais elementar educação. É verdade que os poderes falam hoje muito, com vasta difusão e diuturnamente. Mas só de forma muito indireta se poderá dizer que a sua palavra educa.

\section{SinAIS}

Recordamos a caractereologia ${ }^{14}$. Ao verem repetidamente por vezes o rosto de alguns que enchem os ecrãs, há teleespetadores que efabulam: "quem vê caras não vê corações?" e "Algum ditador tem boa cara, ou 'boa pinta', por acaso'"?

Será que pode haver gente transfigurada pela maldade? Mais nos diz, porém, o seu muito mau gosto, apesar do muito dinheiro e poder que por vezes terá. Muitos têm ar profundamente infeliz. Salvo talvez quando gozam com o mal alheio efémeros momentos de prazer? Tudo isto são meras impressões "vulgares". Sabemos bem que não há "criminosos natos" lombrosianos. É um discurso perigoso, porque pode levar ao contrataque dos autoritários e totalitários, sejam feios ou bonitos.

Mas leva-nos a um outro problema, e grave: será que esta vox populi é assim tão de desprezar, não pela fragilidade da sua ciência, mas pela realidade do cálculo do marketing político, ao se selecionarem candidatos com boa aparência, cada vez mais? Até

\footnotetext{
13 Ferry (2012, p. 243) afirma: "A democracia nos prometia nossa participação na construção coletiva de um universo mais justo e mais livre; ora já perdemos quase todo o controle sobre o desenvolvimento do mundo" - o que não é uma afirmação que nos possa deixar tranquilos. Sobre o processo de tudo a transformar, ser dominado pelo sistema, num outro contexto, porém, ver Lourenço (1967, p. 159).

${ }^{14} \mathrm{E}$ será útil revisitar La Bruyère. Afinal, não escreveu ele que "A saúde e as riquezas, retirando aos homens a experiência do mal, inspiram-lhes a dureza para com os seus semelhantes; e as pessoas dobradas pela sua própria miséria são aquelas que mais se dispõem à compaixão pela miséria do outro" (La Bruyère, 1993, p. 70)?
} 
candidatos sem experiência política. Trata-se apenas de vender uma mercadoria? Esse é que é o problema mais importante de cidadania e democracia neste contexto.

Haveria que recordar Frei Benito Feijó que também refletiu sobre a fisiologia, e cotejá-lo com as conclusões a que chega a atual retórica política: mais do que o traço estático, estuda-se o movimento. A construção do político-ator, porém, não implica, no limite, que se faça uma distinção, ontológica e mais ainda deontológica, entre o real e a sua imitação sentida... Tudo passa assim para um outro nível do jogo, de invenção da personagem e de anulação do sujeito (Cammarosano, 2006; Dal Bosco, 2004, 2007; Figueiredo, 1999; Freitas, 2007). Obviamente que se deve estudar retórica e marketing político para os poder desconstruir também.

A perceção de muitas realidades parece fazer-se pela caricatura, pelo excesso de traços, ou pela comoção, pelo choque. O contraste tem aqui importante papel.

Deve a escola antes de mais ensinar a ver. Educação visual num sentido lato. Perante a hipocrisia e afins, temos de agradecer aos pérfidos a sua perfídia, que alavanca a modesta honradez de alguns para uma quase santidade, como à doença pela valorização da saúde, como à estupidez total pelo contraste com uma pequena inteligência. Giovanni Papini, entre vários motivos para elogio dos néscios, destacava o de serem pano de fundo para os medianamente dotados.

Desde logo, por exemplo, a improbidade administrativa de alguns (como a lei é feita para os maus, e a pensar neles, como se sabe classicamente) terá motivado a resposta legal da defesa dessa mesma probidade' ${ }^{15}$, e a doutrina respetiva (Cammarosano, 2006; Dal Bosco, 2007; Freitas, 2007). A corrupção leva à legislação anti-corrupção, etc. Relembrando Tácito, quanto mais leis, mais sinal pode haver de uma situação anómica: Corruptissima republica plurimae leges (Tácito citado em Mosterín, 2008, s/p). Não olvidemos que Aristóteles já sublinhava que a lei foi feita tendo em atenção os maus.

\section{HiERARQUiAS E DISCRIMINAÇÕES}

As palavras podem incomodar alguns, mas nenhuma democracia sobrevive sem um escol demofílico (Araújo, 1995). Os que, em democracia, clamam contra as elites ou não entenderam a questão, e se encontram presos a complexos românticos, idealistas e literalistas sobre este regime que o deitariam a perder, ou são anarquistas dissolventes, ou saudosistas de velhas segregações e privilégios, ou ainda candidatos a novos. Uma democracia que não trata de formar e selecionar os melhores fica dominada pela mediocridade e pela demagogia. Sendo assim vulnerabilíssima. E as democracias são, realmente, na prática, vulneráveis. Assim

(...) a democracia muitas vezes funciona muito pior do que seria esperado pela facilidade com que demagogos e populistas ganham eleições,

\footnotetext{
${ }^{15}$ Nos termos do art. $37 .^{\circ}, \mathrm{XXII}, \mathbb{\int} 4 .^{\circ}$ da Constituição Federal (1988) "Os atos de improbidade administrativa importarão a suspensão dos direitos políticos, a perda da função pública, a indisponibilidade de bens e o ressarcimento ao erário, na forma e gradação previstas em lei, sem prejuízo da ação penal cabível". É um normativo contundente. Retirado de mpsp. $\mathrm{mp}$.br/portal/page/portal/cao_cidadania/Improbidade_Administrativa/Doutrina_Improbidade/3-improbeaus\%C $3 \% A A n c$ iadepreju\%C3\%ADzo.htm.
} 
especialmente entre as populações desinformadas. Às vezes, os políticos que fazem promessas impossíveis de cumprir são mais populares do que aqueles que têm uma avaliação mais sóbria e realista das possibilidades. $O$ populismo, o caudilhismo e a demagogia, agitam o excesso de confiança dos cidadãos ingénuos na ideia de que os políticos vão resolver os problemas das pessoas (...). (Mosterín, 2008, pp. 53-54)

Demasiado pessimista, mas infelizmente não deixando de bem observar os perigos e calcanhares de Aquiles do rotativismo, afirma o mesmo autor:

Não deve haver ilusões sobre os políticos democráticos, já que podem ser tão corruptos e ineptos como os ditadores. Na verdade, os políticos acabam quase sempre por defaudar os eleitores que, numa próxima eleição escolhem os seus adversários para serem enganados mais uma vez. (Mosterín, 2008, p. 55)

A palavra "elite" tem má fama. E entre nós confunde-se muito "elite" com "oligarquia". E são conceitos e realidades muito diversas. Diríamos mesmo: antagónicas. Porque só com elites se evitam e se combatem os vetores oligárquicos em democracia, que aliás a podem desvirtuar ao ponto de a metamorfosearem.

Quando se diz que uma democracia precisa de elites, afinal de que se trata? De elites de serviço e de virtude, aliadas a competência e sem medo da ideologia. Não se trata obviamente de um clube de papões, nem de uma panela de corruptos, nem de um bando de incompetentes, nem sequer de um punhado de sábios ou especialistas tecnocratas regiamente pagos, pretensamente assépticos, mas ao serviço do statu quo. Ainda se podem unir as elites que restam, ou o que resta das elites.

Mas para isso é preciso um programa, e sobretudo que os "egos" enormes de cada génio se consigam colocar entre parêntesis. E o primeiro compromisso da elite é muito simples: Honrar, Respeitar, Defender, Cumprir e Fazer cumprir a Constituição.

Temos porém que reconhecer que no sentido de um corpo de escol nacional, não há, no nosso entender, qualquer elite digna desse nome em alguns países, hoje. Tanto mais que é preciso que ela tenha consciência de si, se assuma como tal, e queira trabaIhar pelo País. Mas há ainda pessoas que, unidas, podem vir a compor uma elite. E toda a elite verdadeira se deve saber e permanecer suficientemente aberta à sua renovação (condição para que mantenha essa qualidade). Sob pena de se transformar numa oligarquia, evidentemente, quiçá mesmo numa oligarquia falsamente aristocrática.

Do outro lado também há grandes problemas. É preciso não ter medo das palavras, mesmo que desagradáveis ou chocantes: grande obstáculo à educação é a pobreza. Falemos pois dos pobres (Canotilho, 2010, p. 33).

Aristóteles dá-nos sempre avisados tópicos sobre a etiologia (e algum preconceito) sobre uns e outros (Aristóteles, 1960). Mas quem são eles, hic et nunc? Pobres na verdade são hoje os trabalhadores assalariados em geral: aliás, historicamente, o pobre era o que necessitava de trabalhar para viver, opondo-se ao indigente, que se encontrava 
na mais desesperada miséria. Hoje tem de reabilitar-se essa visão, dado, para mais, a enorme precariedade do emprego. O empregado corre sempre o risco de cair na miséria, se se desempregar - designadamente, se for despedido. A barreira entre a pobreza e a indigência é muito ténue.

Mas há um outro passo a dar. Indagar, num perspetiva objetiva, quem são os pobres. Pelo primeiro passo dado, muitos dos que desdenham dos pobres já compreenderão que são igualmente pobres. Isso poderá ser um principium sapientiae para eles...

Depois, é preciso ver, e certamente também com auxílio do espelho, qual o estranhamento, porquê o estranhamento e porquê a segregação e evitamento provocado por esta classe de pessoas - porque pessoas são, e não coisas ou animais, como alguns parece pensarem.

Ora os pobres não são feitos de outra massa, inferior, como tantas vezes deles pensam muitos que o não são, ou julgam não serem... Em parte para acalmarem os seus escrúpulos e aplacarem a sua consciência, se deles estiverem muito distanciados socialmente. Em parte para se distanciarem deles, se se encontrarem perigosamente perto da indigência ou, ao menos, das dificuldades económicas graves.

Os pobres não são mais rudes, mais incultos, menos sutis, mais feios até, e por isso condenados naturalmente à sua condição. Pelo contrário: o que os faz por vezes (e apenas por vezes) assim parecerem é a sua condição de pobres, e, naturalmente, explorados. Não se nasce pobre. Fazemos pobres (parafraseando Beauvoir). Todavia alguns elevam-se, desde logo pela consciência da sua condição, e então, apesar da sua circunstância, são bem mais polidos, cultos, delicados e belos do que os que nadam em marés de contentamentos imerecidos.

Teremos de fazer em relação aos pobres o que até os primeiros navegadores e exploradores acabaram por fazer face aos povos achados, um elogio da sua genuinidade e mesmo beleza ${ }^{16}$ ? Como recorda Paul Lafargue, entre várias outras referências:

Falando dos aborígenes das Ilhas do Pacífico, Lord George Campbell escreve: "Não há pessoas no mundo que sejam atingidas de forma tão impressionante logo desde o início. A sua pele suave e um tom de cobre de luz, os seus cabelos dourados e encaracolados, o rosto bonito e alegre, numa palavra, toda a sua pessoa formou uma nova e esplêndida amostra do 'homo género'; a sua aparência física dava a impressão de uma raça superior à nossa (Lafargue,1880, s/p).

Fica, porém, sempre a suspeita de que o observador, nestes casos, como que se debruça, como afirmava Bazin (1950) para o outro, ainda que o louve. Talvez seja necessário, antes de tudo, um elogio da comum Humanidade não apenas do pobre, categoria cada vez mais vasta, mas do próprio indigente. Humanidade que, sobretudo neste último, tem sido tantas vezes ignorada e ocultada, além de esta mesma condição já revelar a injustiça. Elogio da comum Humanidade, pois, ainda que passe pela sua provisória

\footnotetext{
${ }^{16}$ Ver sobretudo, a Carta de Pero Vaz de Caminha sobre a Descoberta do Brasil (Castro, 2015).
} 
exaltação (e aí os legal storytelling seriam uma via muito adequada): é preciso admirar antes de compreender, para aprender sem desprezar.

No atual estado de coisas, ser rico pode ser uma coisa redobradamente excelente, desde logo, na medida em que permite a mobilização fácil de recursos pela simples vontade de quem o é: e eles podem ser bem usados, e reverter para o Bem Comum (Endress, 1989; Koslowski, 1999) e mesmo para a sociedade (Ackerman, 1993; Azevedo, 2000; Boudon, 1995; Latour, 2003; Craveiro da Silva, 1994; Cunha, 2003; 2010; Tale, 1995).

O grande mal é ser abastado e cego, surdo e mudo perante a realidade social. Nesse caso, a riqueza é certamente um veneno para quem a tem... E nunca se dulcificará o tormento na procura de mais riqueza... Pelo contrário, a insaciabilidade pode ser uma demência, uma tortura.

A sensibilidade ou insensibilidade sociais, a solicitude social ou o seu contrário fazem toda a diferença no clima social de uma vivência jurídico-política. O Estado social, mesmo no seu máximo florescimento, não poderia jamais suprir todas as necessidades sociais. É necessária a colaboração solidária de grandes mecenas e de pequenos esforços e contributos.

Obviamente, com o desmantelamento não progressivo, mas acelerado deste tipo de Estado (Loureiro, 2010) vê-se acrescida a necessidade de a sociedade civil se empenhar solidariamente, cumprindo o seu dever, assumindo a sua responsabilidade social, "dos que podem aos que precisam".

Uma das características da civilização em que vivemos é a importância dada à previsão. Nem sempre bem sucedida, como se vê peças projeções económicas, mas muito querida, não só pelos governos, que se tornaram todos de algum modo planificadores, como dos particulares, a quem se aconselha a que prevejam, assegurem, planifiquem.

Há assim quem tenha grandes planos para a vida, até eventualmente desde muito novo. Nada de mais natural e de mais legítimo. Por exemplo: há quem queira ser isto ou aquilo - quem queira este cargo ou aquele, e muitas vezes apenas pela vaidade de o ter.

A forma como lá chega, com que apoios e com que ideias, ou por que méritos ou deméritos, interessa pouco a esses obstinados. Ora estes são precisamente os que, vistas as coisas pelo prisma da utilidade geral, nunca deveriam atingir as suas metas. Para o bem público. Porque se interessam só pelos fins e não pelos meios.

Ora nos meios está não só toda a beleza do caminho, como toda a legitimidade do percurso... e eventualmente da chegada.

Há vários tipos de ambição. Aristóteles já o tinha observado nas "Éticas a Nicómaco" (Aristóteles, 2009). Nota-se até a falta de uma palavra para ambição positiva, ou, se preferirmos, para ambição negativa... Porque sabemos, com o Estagirita, que a virtude está no meio: nem é virtuoso o abúlico que nada deseja, e absolutamente por nada se esforça (nem sequer é preguiça, é um amodorramento, em boa medida confundível com resignação, embrutecimento, etc.) nem o ambicioso arrivista, fura-vidas, videirinho, etc. Ora, o bom ambicioso, esse, como lhe poderíamos chamar? Mais importante do que isso - que virtudes tem ele de possuir?

É que a boa ambição tem de exercer-se para o bem comum. Recordando de novo Aristóteles, não é por acaso que ele, depois de discutir se a vida privada é melhor que a 
pública, ou vice-versa, acaba por se inclinar para a excelência do envolvimento na vida pública. Cremos que a razão mais profunda é a mesma sobre a excelência da virtude da Justiça, face às demais. É que, enquanto as outras se exercem sozinhas, e podem no limite ter um efeito apenas sobre o próprio, ou um círculo fechado, a Justiça, como a intervenção na coisa pública, é necessariamente algo com alcance social. Melhor é pois o bem político, que a todos, ou pelo menos ao maior número, pode beneficiar.

Nota-se em vários países uma cada vez mais potenciada confusão social e de valores pela ascensão dos "novos-ricos": a mania das grandezas pessoais, traduzida pela mania da nobreza e agora da ostentação de verdadeiros e falsos títulos académicos e distinções afins... Não é coisa que se consiga abolir por decreto... Se acabarmos com os doutores, vão os social climbers imediatamente redescobrir baronatos ou comendas...

Esta situação tem contudo uma leitura mais preocupante. Os títulos são sinais que se emitem para a sociedade. E o excesso desses sinais, quantas vezes falsos e falsificados, significa que somos sociedades onde a dignidade simples de se ser cidadão não é tomada a sério, e se precisa de adjetivos para se ser considerado. Além da vaidadezinha, é um sinal preocupante. Ao britânico, chega miticamente ser súbdito de Sua Majestade. A nós, devia bastar-nos a altivez de sermos cidadãos das nossas Repúblicas. Mas a muitos não chega.

Uma curiosidade: Como no império bizantino os doutores estavam equiparados a condes e os advogados a doutores... Podemos nós todos, juristas, ou quase todos de entre nós, dizer que somos condes! Porém, parece que o tratamento dado aos condes é o de "Senhor"!

Para lá da incomodidade que possa suscitar, para quem tem com relativa estabilidade o seu lugar (alto ou baixo) na sociedade, o ruído da avidez de status e da confusão de maneiras e códigos de quem se vê com muito dinheiro não reconhecendo a sua escassa educação, importará ponderar sobre o fenómeno friamente. Os novos-ricos são, afinal, resultado da roda da fortuna das nossas sociedades baseadas no ter, é certo, mas são também, em algum grau, produto de um aspeto positivo das nossas sociedades abertas: são sinal de que a mobilidade social ascendente é possível. Talvez nem sempre por mérito intelectual, ou como prémio do esforçado trabalho, mas sem dúvida por alguns motivos nobres.

Recordemos, pois, que numa sociedade social fechada, estratificada, de rígidas castas, ou estamentos blindados, não há novos-ricos. E esse tipo de sociedade é muito pior que as gaffes pueris e a ingenuidade por vezes cobiçosa de uns tantos fadados pela sorte ou mesmo premiados por trabalho e qualidades.

Evidentemente, pois, que a solução não é bloquear a ascensão social. Pensemos que não haverá o fenómeno dos "novos-ricos" se todos estiverem educativamente preparados tanto para ter como para não ter. Se a educação for universal e igualitária nas suas bases. E note-se ainda que também não haverá, por outras razões, este estrato novo, se se conseguir consolidar (e não espoliar permanentemente como à galinha dos ovos de oiro) uma classe média, alargada e com conciência, com muitos graus entre ricos e indigentes. 
Infelizmente, é preciso, antes de mais, reconhecê-lo: em matéria de convivência (e até de tolerância), caído o verniz (e eles está a estalar por todos os lados: já se fala nuns países, e noutros já se parece ter começado a praticar, a expulsão de grupos como os ciganos, para dar apenas um exemplo...) estamos ainda na pré-história. Seria urgente, desde a escola mais elementar, e com programas inteligentes na televisão e noutros meios de comunicação social preparar as pessoas para aceitar as diferenças. O ideal seria mesmo: para as valorizar. Porque elas fazem parte do património comum, da humanodiversidade, na verdade muito mais importante que a biodiversidade, que justamente se quer preservar.

Proscrever retoricamente racismo, xenofobia, homofobia, etc. é um passo ainda muito pequenino. Há ódios inimagináveis contra o que veste de cor ou feitio diferente, que fará contra o que ousa pensar de outro modo, e mais ainda contra o que se atreve a agir diversamente!? Em muitos aspetos ainda numa profunda menoridade nos encontramos. E como, numa situação destas, não convocar o Direito Constitucional, como projeto social comum, e, neste caso, grande pedagogia de convivência?

Como vimos, a Educação é uma necessidade vital, e, como tal, pode mesmo ser considerada um direito natural. Mas tal direito esbarra com escolhos da mais variada ordem, numa sociedade em que, mais que os direitos, imperam duras realidades e os seus poderes não juridicamente legitimados.

\section{REFERÊNCIAS BIBLIOGRÁFICAS}

Ackerman, B. (1993). La justicia social en el estado liberal. Madrid: Centro de Estudios Constitucionales.

Aires, M. (1752). Reflexões sobre a vaidade dos homens, ou discursos morais sobre os efeitos da vaidade. Lisboa: Oficina de Francisco Luís Ameno.

Araújo, A. C. (1995). O poder e as elites: a caminho de um elitismo democrático. Tese de Mestrado. Lisboa: Universidade de Lisboa.

Aristóteles (1960). Rhétorique. Paris: Les Belles Lettres.

Aristóteles (1987). Organon V. Lisboa: Guimarães Editora.

Aristóteles (2009). Ética a Nicómaco, IV. Lisboa: Quetzal Editores

Azevedo, P. F. (2000). Direito, justiça social e neoliberalismo. São Paulo: Editora Revista dos Tribunais.

Bachrach, P. (1969). The theory of democratic elitism - A Critique. Londres: University of London Press.

Barthes, R. (1970). Mitologias. Lisboa: Edições 70.

Bauman, Z. (2010). Legisladores e intérpretes. Rio de Janeiro: Zahar.

Bazin, H. (1950). A morte do cavalinho. Lisboa: Editores Associados.

Beard, H. \& Cerf, C. (1994). Dicionário do politicamente correto. Porto Alegre: L\&PM.

Benda, J. (1927). La trahison des clercs. Paris: Grasset. 
Black, V. (s.d.). Introdução a "Do orador" e outros textos. Porto: Rés.

Blais, M.-C. (2007). La solidarité. histoire d'une idée. Paris: Gallimard.

Botelho, A. (1996). Teoria do amor e da morte. Lisboa: Fundação Lusíada.

Boudon, R. (1995). Le juste et le vrai. Paris: Fayard.

Brecht, B. (1976). Poemas - A solução. Lisboa: Editorial Presença.

Bruce, A. (1993). La justicia social en el estado liberal. Madrid: Centro de Estudios Constitucionales.

Caggiano, M. H. (2011). Democracia X constitucionalismo: um navio à deriva? Cadernos de Pós-Graduação em Direito: Estudos e Documentos de Trabalho, 1, 5-24. Retirado de http://www.direito.usp.br/pos/arquivos/ cadernos/caderno_1_2011.pdf

Calafate, P. (1999). História do pensamento filosófico Português. Lisboa: Caminho.

Cammarosano, M. (2006). O princípio constitucional da moralidade e o exercício da função administrativa. Belo Horizonte: Forum.

Castro, S. (2015). A Carta de Pero Vaz de Caminha. O Descobrimento do Brasil. Porto Alegre: L\&PM.

Canotilho, J. J. G. (2010). O direito dos pobres no activismo judicial. In J. J. G. Canotilho; M. O. Correia \& E. P. B. Correia (Eds.), Direitos Fundamentais Sociais (pp. 33-36). S.Paulo: Saraiva.

Chiossone, T. (1987). La conducta de la autoridad como factor criminogeno. Revista de la Facultad de Ciencias Juridicas y Politicas. Retirado de http://www.ulpiano.org.ve/revistas/bases/artic/texto/RDUCV/67/ rucv_1987_67_7-20.pdf

Cunha, P. F. (2003). O século de Antígona. Coimbra: Almedina.

Cunha, P. F. (2005). Política mínima. Coimbra: Almedina.

Cunha, P. F.(2005a). A escola a arder. Lisboa: O Espírito das Leis.

Cunha, P. F. (2010). Para uma ética republicana. Lisboa: Coisas de Ler.

Cunha, P. F. (2011). Esclavage. In S. Tzitis, G. Bernard \& D. Joliver (Eds.), Dictionaire de la Police et de la Justice (pp. 124-125). Paris: Dalloz.

Cunha, P. F. (2011a). Universidade: um manifesto pelo sonho. In J. \&. Lauand, Filosofia e Educação. Universidade (pp. 13-24). São Paulo: CEMOrOC/Factash.

Cunha, P. F. (2012). O avesso dos direitos humanos. Para uma história pensada da escravatura. Curitiba: Juruá.

Cunha, P. F. (2016). Para um guia metódico do estudante de Direito - Introdução ao espírito universitário dos juristas. Notandum, 40, 125-146. Retirado de http://hottopos.com/notand40/125-146PFC.pdf

Dal Bosco, M. G. (2007). Discricionaridade em políticas públicas. Curitiba: Juruá.

Dal Bosco, M. G. (2004). Responsabilidade do agente público por ato de improbidade. Rio de Janeiro: Lumem Juris.

Debord, G. (1992). La société du spectacle. Paris: Gallimard.

Debret, R. (1993). L'État séducteur. Paris: Gallimard. 
Derrida, J. (1991). L'autre cap suivi de la démocratie ajournée. Paris: Minuit.

Endress, J. (1989). Geimeinwohl heute. Innsbruck: Tyrolia.

Ferry, L. (2012). Aprender a viver. filosofia para os novos tempos. Rio de Janeiro: Objetiva.

Figueiredo, M. (1999). O controle da moralidade na constituição. São Paulo: Malheiros.

Fiske, J. (1999). Teoria da comunicação. Porto: ASA.

Freitas, J. (2007). Discricionaridade administrativa e o direito fundamental à boa administração pública. São Paulo: Malheiros.

Fumaroli, M. (1994). L'école du silence, le sentiment des images au xviie siècle. Paris: Flamarion.

Gillman, M. A. (1996). Envy as a retarding force in science. Avebury: Aldershot/Brookfield.

Guitar Escudero, M. P. (2005). Discurso parlamentario y lenguaje politicamente correcto. Madrid: Congressos de los Diputados.

Hall, E. (1959). The silent language. Nova Iorque: Donbleday.

Kant, I. (1988). Que és ilustración? Madrid: Tecnos.

Koslowski, P. (1999). Das gemeinwohl zwischen universalismus und particularismus. Stuttgart/Bad Cannstatt: Frommann-Holzboog.

Lafargue, P. (1880). Le droit à la paresse. Retirado de https://www.marxists.org/francais/lafargue/ works/1880/oo/lafargue_18800000.htm\#3

Latour, S. (2003). A sociedade justa. Igualdade e diferença. Porto: Porto Editora.

La Boétie, E. D. (1997). Discurso sobre a servidão voluntária. Porto: Antígona.

La Bruyère, J. (1993). Les caractèteres de Théophraste traduits du grec avec les caractères ou les moeurs de ce siècle. Paris: Booking International.

Lembo, C. (2006). Eles temem a liberdade. Barueri: Cepes/Manole/Minha Editora.

Loureiro, J. (2010). Adeus ao Estado Social? Coimbra: Wolters Kluwer/Coimbra Editora.

Lourenço, E. (1967). Heterodoxia II. Coimbra: Coimbra Editora.

Moreira, A. C. (1995). O Poder e as elites: a caminho de um elitismo democrático. Tese de Mestrado, Universidade de Lisboa, Lisboa, Portugal.

Mosterín, J. (2008). La cultura de la libertad. Madrid: Espassa Calpe.

Nakagawa, H. (2008). Introdução à cultura japonesa. Ensaio de Antropologia recíproca. São Paulo: Martins Fontes.

Quintino, C. A. (2007). O conceito de exclusão social numa abordagem liberal e estruturalista. In Anais do VI Simpósio Multicultural do UNIFAI (pp. 203-223). São Paulo: IESP/UNIFAI.

Rousseau, J. J. (2010). Du contract social. Rosny: Bréal.

Ryner, A. (1996). L'envers du Théâtre. Dramaturgie du silence de l'âge classique à Maeterlinck. Paris: Jose Corti. 
Silva, L. C. (1994). Marxismo, filosofia da libertação. In L. Craveiro da Silva, Ensaios de Filosofia e Cultura (pp. 365-378). Braga: Faculdade de Filosofia.

Sartori, G. (1994). Comparative constitutional engineering. New York: University Press.

Tale, C. (1995). Lecciones de filosofia del derecho. Córdova: Alveroni.

Vilhena, V. (1942). Pequeno manual de Filosofia. Lisboa: Sá da Costa.

\section{OUTRAS REFERÊNCIAS}

Antunes, A. (s.d). O Estudante Alsaciano. Retirado de http://www.blocosonline.com.br/literatura/poesia/pioı/ pi210548.htm

Emmerich, R. (Realizador) (2009). 2012. USA: Columbia Pictures [Filme]

\section{NotA BIOGRÁFICA}

Paulo (Jorge Fonseca) Ferreira da Cunha (n. Porto, 1959) é constitucionalista e cultor da filosofia do direito e da política, Professor Catedrático de Direito da Faculdade de Direito da Universidade do Porto (desde 2001) e Diretor do Instituto Jurídico Interdisciplinar (desde 2002). Com o seu livro Direito Constitucional Geral (editado em Portugal pela Quid Juris e no Brasil pela Método) ganhou um dos Prémios Jabuti para o melhor livro de Direito em 2007, e em 2006 menção honrosa do Prémio da Sociedade Histórica da Independência de Portugal pelo seu Lusofilias, editado pela Caixotim.

E-mail: paulomfcunha@gmail.com

Universidade de Coimbra

* Submetido: 24-09-2015

* Aceite: 30-09-2015 